\title{
Al-Quran Literacy for Early Childhood with Storytelling Techniques Dewi Mulyani ${ }^{1}$, Imam Pamungkas ${ }^{2}$, Dinar Nur Inten ${ }^{3}$ \\ Fakultas Tarbiyah dan Keguruan - Universitas Islam Bandung (UNISBA)
}

\begin{abstract}
Muslim children are part of the Muslims. They are the successors and propagators of the da'wah of the Muslims. It is an obligation for parents and teachers to provide them with the ability to read, write and understand the Qur'an as a guide for the lives of Muslims. With the literacy of Al-Quran from an early age, it is expected the generations of Muslims to understand and literate the guidelines of his life. However, children are different from adults. Early childhood teachers should choose the right techniques for early childhood. Children love the sound playing, fun, and freedom from stress. In this case, is offered one of the techniques favored by early childhood, that is storytelling techniques. This research method descriptive analytic with a qualitative approach. So that's this method can produce a clearer picture of Al-Quran literacy strategies for early childhood. In operational research, researchers conduct interviews, observation literature studies. The results showed that $75 \%$ of children in group A enjoyed Quranic literacy with storytelling techniques and in group B children 41,6\% liked it too. Thus Al-Quran literacy through storytelling techniques is a fun and meaningful activity.
\end{abstract}

Keywords: literacy of al-quran, early childhood, storytelling technique

\begin{abstract}
Abstrak
Anak-anak muslim merupakan bagian dari kaum muslimin. Mereka adalah penerus dan penyambung dakwah kaum muslimin. Sudah menjadi kewajiban bagi orangtua dan guru untuk membekalinya dengan kemampuan membaca, menulis dan memahami Al-Quran sebagai pedoman hidup kaum muslimin. Dengan literasi Al-Quran sejak dini, diharapkan generasi muslimin memahami dan melek pedoman hidupnya. Namun demikian, anak-anak berbeda dengan orang dewasa. Guru anak usia dini harus memilih teknik yang tepat bagi anak usia dini. Anak-anak menyukai suasanya bermain, menyenangkan, dan terbebas dari tekanan. Dalam hal ini ditawarkan salah satu teknik yang disukai oleh anak usia dini, yaitu teknik bercerita. Metode penelitian ini deskriptif analitik dengan pendekatan kualitatif. Sehingga dengan metode ini dapat menghasilkan gambaran yang lebih jelas mengenai strategi literasi Al-Quran untuk anak usia dini. Dalam operasional penelitian, peneliti melakukan wawancara, pengamatan dan studi pustaka. Hasil penelitian menunjukkan $75 \%$ anak kelompok A menyenangi dan dapat mengikuti pembelajaran literasi Al-Quran dengan teknik bercerita dan pada anak kelompok B 41,6\%. Dengan demikian literasi Al-Quran melalui teknik bercerita menjadi kegiatan yang menyenangkan dan bermakna.
\end{abstract}

Kata Kunci: literasi al-quran, anak usia dini, dan teknik bercerita

@ Jurnal Obsesi Prodi PG-PAUD FIP UPTT 2018

$\triangle$ Corresponding author :

Address : Bandung Jawa Barat

Email : dewiemulyani@gmail.com

ISSN 2356-1327 (Media Cetak)

ISSN 2549-8959 (Media Online) 


\section{PENDAHULUAN}

Bagi umat Islam, al-Quran merupakan salah satu sumber utama (almarja' al-awwal) dalam mengemban tugas kekhalifahannya, itulah pernyataan Anwar(Anwar, 2014) untuk menujukkan betapa pentingnya Al-Quran sebagai pedoman hidup kaum muslimin. Dengan menjadikan Al-Quran sebagai rujukan utama dalam menjalankan kehidupan sebagai pemimpin di muka bumi, Allah menegaskan bahwa hanya dengan berpegang teguh kepada Al-Quran sukses di dunia dan akhirat dapat diraih. Namun demikian masih banyak umat Islam yang jangankan untuk memehami dan menjadikannya sebagai pedoman, membacanya pun masih belum bisa dan belum lancar.

Sebagaimana dilansir dalam Pikiran Rakyat 2017, dari sekitar 225 juta muslim, sebanyak $54 \%$ diantaranya termasuk kategori buta huruf Al-Quran, jadi baru $46 \%$ muslim yang melek AL-Quran dan mampu membaca Al-Quran. Jika dimasukkan pada indikator memahami AlQuran tentu akan lebih kecil lagi.Hal ini sungguh memprihatinkan. Padahal, umat Islam masih mayotitas di Indonesia. Diungkap Republika (25 Juni 2018), meski merupakan negara mayoritas Muslim terbesar di dunia, namun hanya sekitar 0,5 persen umat Islam di Indonesia yang mampu membaca Al-Quran dengan baik. Berdasarkan riset IIQ (Institut Ilmu AlQuran), tingkat buta huruf Al-Quran di Indonesia masih terbilang cukup tinggi, tercatata $65 \%$ masyarakat Indonesia buta huruf Al-Quran sebagai mana dilansir Republika (17 Januari 2018).

Gambaran kondisi tersebut sungguh hal yang memprihatinkan bagi kalangan umat Islam. Betapa tidak dari jumlah mayoritas pemeluk agama Islam di Indonesia, kemampuan umat Islam dalam membaca Al-Quran masih sangat rendah. Padahal Al-Quran sebagai pedoman hidup bagi kaum muslimin. Oleh karena itu gerakan pemberantasan buta huruf AlQuran perlu digalakan. Rutinitas membaca, menulis dan mengkaji kandungan Al-
Quran seharusnya ditanamkan sejak usia dini.

Jika ditelusuri, kondisi kemampuan membaca Al-Quran umat Islam tersebut salah satu penyebabnya adalah kesan pertama yang tidak menyenangkan ketika belajar membaca dan menulis Al-Quran dalam hal ini penulis sebagai literasi AlQuran. Hal ini terlihat dari proses belajar yang tidak bermakna bagi anak, anak tidak merasa senang ketika belajar karena teknik-teknik yang digunakan guru dalam mengenalkan Al-Quran (literasi Al-Quran) tidak cocok untuk anak dan tidak sesuai dengan perkembangan anak. Guru di lembaga-lembaga PAUD masih menggunakan teknik konvensional, menuntut anak duduk diam mendengarkan dan menuliskan. Padahal bagi anak duduk diam menulis dengan alat tulis yang masih asing digenggamannya merupakan hal yang sulit. Terlebih yang mereka pelajari adalah membaca dan menulis Al-Quran. Dengan demikian, bagi anak usia dini, belajar menulis dan membaca Al-Quran menjadi hal yang membosankan dan jauh dari kata membahagiakan.

Sesungguhnya, masa usia dini adalah masa yang sedang subur untuk menanam benih-benih sikap, nilai, dan minat. Masa ini menjadi awal pembelajaran dan penggalian potensi untuk anak. Masa pra sekolah (usia Taman Kanak-Kanak) merupakan masa yang paling subur untuk menanamkan rasa agama kepada anak, umur penumbuhan kebiasaan-kebiasaan yang sesuai denganajaran agama, melalui pendidikan dan perlakukan dari orangtua dan guru (Yusuf, 2004). Masih menurut Yusuf, sejak usia dini anak sudah dapat diajarkan rukun iman, rukun Islam, bacaan dan pengertian dua kalimah syahadat, bacaan dan gerakan shalat, doa-doa, membaca dan menulis Al-Quran dan riwayat para Nabi.

Pada dasarnya, pembelajaranawal literasi Al-Quran pada anak harus memperhatikan prinsip-prinsip pebelajaran untuk anak usia dini, di antaranya adalah (1) memperhatikan tingkat perkembangan, kebutuhan, minat, dan karakteristik anak. (2) Mengintegrasikan kesehatan, gizi, 
pendidikan, pengasuhan, dan perlindungan.

(3) Pembelajaran dilaksanakan melalui bermain. (4) Kegiatan pembelajaran dilakukan secara bertahap, berkesinambungan, dan bersifat pembiasaan, (5) Proses pembelajaran bersifat aktif, kreatif, interaktif, efektif, dan menyenangkan. (6) Proses pembelajaran berpusat pada anak. (Departemen Pendidikan Nasional, 2009). Hal -hal tersebut penting diperhatikan agar anakanak menyukai kegiatan membaca dan menulis awal Al-Quran. Semua harus dilakukan dengan berdasar pada program tahap-demi tahap sesuai dengan perkembangan anak. Seperti pengenalan bentuk huruf hijaiyah dan pengucapan huruf hijaiyah.

Dengan ini, penting bagi orangtua dan guru untuk menggiatkan literasi AlQuran padaanak-anakdengan teknik yang ramah dan sidukai anak-anak usia dini.Dalam tulisan ini penulis mengkaji penggunaan teknik bercerita untuk pengenalan literasi Al-Quran pada anak usia dini. Bercerita merupakan salah satu teknik dianggap salah satu teknik yang disukai anak, selain bermain dan bernyanyi. Tandayu (Tandayu, 2001) menyatakan bahwa secra umum terkait ftrahnya, anak-anak menyukai kegiatan bernuansa B-C-M, yaitu bermain, bercerita dan bernyanyi. Untuk itu, segala unsur pendidikan yang tepat diberikan kepada anak-anak adalah bertolak dari sudut pandang dunia mereka.

Cerita memiliki daya tarik tersendiri, sebagaimana masih dari Tandayu(Tandayu, 2001) bahwa dunia anak-anak adalah dunia yang kaya dengan fantasi. Pada umumnya, anak-anak akan penuh minat mendengarkan sesuatu yang mengarah kepada eksploitasi imajinasi dan daya fantasinya, seperti cerita-cerita yang disampaikan dengan gaya visualisasi yang hidup dan eksptesif. Semua itu memang bealasan karena sifat dasar anak memiliki rasa ingin tahu yang tinggi terutama pada hal-hal yang baru, aneh, dan rahasia dan fantasi.

Dari pemaparan tersebut, maka peneliti akan meneliti lebih mendalam mengenai kegiatan literasi Al-Quran pada anak usia dini di RA Al-Muqoddasah Jagabaya Banjaran Kabupaten Bandung sehingga dapat terlihat benang merah antara teori pengajaran Al-Quran untuk anak, teori perkembangan anak dan teknik yang sesuai di gunakan untuk pengajaran literasi Al-Quran bagi anak usia dini.

Literasi adalah kemampuan untuk membaca dan menulis teks serta kemampuan untuk memaknai (UNESCO, 2005: 148). Secara sederhana pengertian literasi disampaikan Barrat (2000: 2), Literacy is how the children learn to read and write. Pengertian lain disampaikan (Aminudin, 2005), literasi adalah kemampuan untuk mengidentifikasi, mengerti, mengartikan, menciptakan, mengkomunikasikan, dan menghitung menggunakan materi cetak dan tertulis sehubungan dengan berbagai konteks yang berbeda-beda. Berbeda dengan Neneng (2017: 22), literasi tidak hanya terpaku pada membaca dan menulis saja. Namun, kemampuan seorang anak untuk mengidentifikasi, memahami, mengkritisi, dan menciptakan akan terangsang apabila memiliki gairah membaca dan menulis yang tinggi. Oleh sebab itu, membaca dan menulis dapat dikatakan kemampuan dasar yang harus dimiliki untuk membangun kemampun literasi yang utuh.

Al-Quran merupakan pedomam pokok umat Islam. Menjadi keniscayaan untuk umat Islam memahami Al-Quran. Sebelum memahami Al-Quran, seorang muslim harus dapat membacanya. Untuk itulah gerbang pemahaman terhadapa agama Islam adalah memahami dan mampu membaca juga menulis kita suci Al-Quran. Tahalib (1995: 103) menyatakan bahwa setiap orang dapat dikatakan benar dalam menjalankan kewajiban agama Islam jika ia dapat membaca dan memahami Al-Quran dalam bahasa aslinya, bukan lewat traskripsi atau terjemahan. Thalib (Thalib, 1995) juga menambahakan bahwa anak-anak kita sebagai bagian dari umat Islam sudah dengan sendirinya wajib kita ajari membaca Al-Quran, minimal mengenal huruf dan cara membacanya. Karena sejak 
umur tujuh tahun kita wajib menyuruh anak-anak untuk shalat. Sedangkan doa dan bacaan shalat ada dalam Al-Quran dan hadis. Oleh sebab itu, logislah setiap orangtua muslim mengajarkan membaca dan menulis Al-Quran guna memenuhi kewajiban beribadah kepada Allah, seperti shalat.

Literasi dini disebut juga dengan literasi emergen (Musthafa, 2008:2). Teale \& Sulbzy (1998) menyatakan bahwa literasi emergen secara umum digunakan untuk merujuk pada proses menjadi terliterasi atau melek huruf (Astuti, 2012). Maka dalam literasi Al-Quran untuk anak usia dini bentuknya adalah menumbuhkan dan mengenalkan anak kepada Al-Quran baik dari aspek membaca maupun menulis.

Anak usia dini menurut UU Sisdiknas No. 20 Tahun 2003 adalah kelompok manusia yang berusia 0 sampai dengan 6 tahun. Papalia, Olds, dan Feldman (Papalia \& Olds, 2002)menyatakan bahwa anak usia dini berada pada rentang usia 0-8 tahun. Pada masa ini proses pertumbuhan dan perkembangan dalam berbagai aspek sedang mengalami masa yang cepat dalam rentang perkembangan hidup manusia.

Sulaiman (Sulaiman, 2000) menyatakan bahwa masa sebelum sekolah (usia antara 3 sampai 6 tahun) merupakan fase yang sangat penting dan serius. Banyak pendidik yang tidak menyadarinya. Fase ini merupakan fase dasar yang menjanjikankeberhasilan mendidik dengan baik. Seumpama sebatang pohon, jika akarnya kuat maka dengan mudah pucuknya menjulang ke langit. Pernyataan Abu Amr Ahmad Sulaiman tersebut merupakan perumpamaan terhadap gambaran tumbuh kembang sebuah pohon yang dapat pula dianalogikan terhadap tumbuh kembang anak manusia. Masa usia dini disebut sebagai masa kritis karena masa itu masa penting untuk peletakan dasar-dasar kepribadian, moral, nilai, emosi, sosial, fisik-motorik dan aspekaspek perkembangan lainnya. Masa ini tidak akan bisa terulang dan akan menentukan masa-masa selanjutnya. Berbicara anak usia dini adalah berbicara konteks sekarang yang akan sangat mempengaruhi periode perkembangan manusia selanjutnya.

Bagaimana orangtua mengajarkan Al-Quran kepada anak-anaknya? Pertama, mengajarkannya sendiri. Ini menjadi cara yang terbaik, karena orangtua lebih akrab dengan anaknya dan lebih tahu tingkat kemampuan dan perkembangan anakanaknya. Dalam hal ini makan orangtua dituntut lebih dahulu tahu membaca dan memahami Al-Quran sebelum anakanaknya. Kedua, menyerahkan kepada guru mengaji Al-Quran atau memasukkan anak-anak di sekolah yang mengajarkan baca-tulis Al-Quran. Ketiga, dengan alat yang lebih canggih, dapat mengajarkan AlQuran lewat video, kaset, jika orangtua mampu menyediakan peralatan semacam itu (Thalib, 1995). Dalam hal ini orangtua dan guru dapat bekerjasama menyediakan media dan teknik yang sesuai dan disukai oleh anak. Sholehudin (Sholehudin, 1997)menegaskan bahwa bermain, bercerita, dan bernyanyi untuk sebagian orang menganggapnya hanyabersenangsenang dan menghabiskan waktu, padahal sebenarnya bias berkontribusi banyak terhadap proses belajar dan perkembangan anak usia dini. Pembelajaran membaca dan menulis Al-Quran dengan cara membosankan dan bersifat tentu tidak sesuai untuk anak usia dini, salah satu cara memperkenalkan anak pada kegiatan membaca dan menulis Al-Quran yang menyenangkan adalah dengan bercerita atau berdongeng.

Teknik bercerita menjadi salah satu teknik yang ditawarkan untuk pengenalan literasi Al-Quran kepada anak usia dini. Mengapa melalui teknik bercerita? Jawabannya, siapa yang tidak suka mendengarkan cerita? Tua muda tentu menyukainya. Saat di mana anak mengembangkan imajinasi dan memperluas minatnya adalah ketika ia mendengarkan cerita (Bunanta, 2008). Cerita merupakan suatu aktivitas yang memiliki nilai banyak bagi proses belajar dan pembelajaran anak. Musfiroh(Musfiroh, 2005) mengatakan bercerita adalah salah satu cara 
menyampaikan informasi dalam proses pembelajaran pendidikan, khususnya bagi anak-anak usia 4-6 tahun di TK. Kegiatan bercerita dapat menciptakan suasana menyengangkan, merangsang proses kognisi, mengembangkan kesiapan dasar Bahasa dan literacy serta dapat berfungsi membangun hubungan yang akrab (Sholehudin, 1997).

Literasi Al-Quran pada anak usia dini dikenalkan melalui pembelajaran yang berkaitan erat dengan dunia anak dan sesuai perkembangannya. Suasana pembelajaran yang nyaman akan menjadikan anak tertarik, menikmati pembelajaran dengan tanpa beban dan tekanan. Anak melakukan proses belajar dari pengalaman hidupnya. Pengalaman yang baik dan menyenangkan akan berdampak positif bagiper kembangananak. Anak belajar dari segala yang ia lihat, ia dengar dan ia rasakan. Proses belajar anak akan berjalan efektif apabila anak dalam keadaan senang dan bahagia. Sebaliknya, proses belajar ada yang dipaksakan atau diterima anak dalam suasana takut, cemas, was-was, dan perasaan lain yang tidak nyaman, tidak akan mampu memberikan hasil yang optimal. Pembelajaran membaca dan menghafal Al-Quran yang yang disamapaikan dengan cara menyenangkanakan berpengaruh baik pada perkembangan jiwa anak(Sulaeman, 2007).

Perkenalan anak pada kegiatan literasi Al-Quran merupakan proses awal untuk mengetahui dan memahami isi dan ajaran yang terkadung dalam Al-Quran. Proses awal memahami Al-Quran tersebut salah satunya terwujud dalam kegiatan bercerita. Andalusia (Andalusia \& Dkk., 2017) menyatakan dengan bercerita, anak memperoleh informasi mengenai dunia, suatu keadaan di berbagai daerah, karakter manusia yang beragam, dan kebiasaan serta nilai yang dimiliki sebuah kebudayaan. Metode mendongeng merupakan salah satu cara ampuh dalam menanamkan moral pada anak usia dini karena anak dapat berimajinasi, meniru karakter yang dimainkan dimana tokoh tersebut akan menjadi panutan yang baik bagi anak (Putri, 2017).

Kegiatan bercerita untuk anak usia dini memiliki banyak manfaat, Itaz (2008: 81-97) menguraikan sejumlah manfaat bercerita yaitu, membantu pembentukan pribadi dan moral anak, menyalurkan kebutuhan imajinasi dan fantasi anak, memacu kemampuan verbal anak, merangsang minat menulis anak, merangsang minat baca anak, serta membuka cakrawala pengetahuan anak. Terkait kegiatan bercerita dan kemampuan menulis anak, Itaz (2008: 88) menyatakan bahwa cerita juga membantu menumbuhkan kemampuan tulis (emergen writing) anak. Cerita dapat menstimulasi anak membuat cerita sendiri. Anak terpacu menggunakan kata-kata yang diperolehnya, dan terpacu menyusun katakata dalam kalimat dengan perspektif dongengnya sendiri. Anak lebih cepat menguasai kata dan struktur kalimat dalam sudut pandang akuan (orang pertama) dan diaan (orang ketiga). Dan literasi Al-Quran melalui teknik bercerita pada kegiatan menceritakan kembali mengantarkan anak untuk dapat mengenal lebih mendalam mengenai berbagai cerita dalam Al-Quran sekaligus memperkaya kosata bahasa Arab anak. Kemampuan bahasa anak utamanya pengenalan kosakata dapat ditingkatkan melalui kegiatan menceritakan kembali isi cerita oleh anak (Fauziddin, 2017)

Menstimulasi minat baca lebih penting daripada mengajarkan mereka membaca. Menstimulasi memberi efek menyenangkan, sedangkan mengajar seringkali justru membuhun minat baca anak, apalagi jika hal tersebut dilakukan dengan cara paksa. Pengalaman menujukkan, anak-anak yang dibiarkan berkutat secra katif dengan lingkungan baca memiliki minat dan kemampuan baca lebih besar daripada anak-anak yang diajarkan membaca melalui drill (Itaz, 2008: 94). Dengan demikian guru dan orangtua lebih penting menstimulus minat baca daripada mengajarkan membaca kepada anak usia dini. Menstumulasi ini dapat dilakukan salah satunya dengan kegiatan bercerita. 


\section{METODE PENELITIAN}

Penelitian kali ini menggunakan metode deskriptif analitis dengan pendekatan kualitatif. Diharapkan dengan metode ini akan tergali informasi yang mendalam tentang pokok permasalahan yang telah disebutkan sebelumnya. Selain itu, penelitian ini juga akan menganalisis tentang beberapa hal yang diteliti, sehingga akan menghasilkan sebuah gambaran yang jelas tentang Literasi Al-Quran untuk Anak Usia Dini dengan teknik Bercerita. Dalam pelaksanan penelitian ini dilakukan wawancara, pengamatan serta studi pustaka.

Penelitian ini dilakukan kepada siwasiswa di RA Al-Muqoddasah Kabupaten Bandung. Adapun sumber data utama dalam penelitian di antaranya: kepala sekolah, guru, siswa, serta data tertulis (buku-buku dan dokumen). Adapun jenis data yang diperlukan adalah data primer, yaitu berupa hasil wawancara dan pengamatan tentang Literasi Al-Quran Untuk Anak Usia Dini dengan Teknik Bercerita, seperti RPPM, RPPH, skenario pembelajaran, dan pendekatan. Data sekunder, yaitu data yang diperoleh berupa karya siswa, dokumen penilaian perkembangan kemampuan literasi AlQuran anak, dokumen foto dan video proses pembelajaran literasi Al-Quran. Penggalian data sekunder ini dilakukan sebelum terjun ke lapangan dan sebagian dilakukan pengumpulannya saat proses penelitian ini berlangsung.

Proses penelitian dilakukan secara bertahap. Pada langkah awal dimulai dengan pengumpulan data (data collection). Kemudian hasil dari pengumpulan tersebut direduksi. Kegiatan reduksi ini melingkupi merangkum, memilih hal-hal pokok dan memfokuskan pada hal-hal penting dari sejumlah data lapangan yang telah diperoleh dan mencari polanya. Penelitian ini menggunakan teknik pengumpulan data melalui pengamatan atau observasi wawancara, dan analisis dokumen (metode historis). Penelitian ini dilaksanakan melalui tahaptahap observsi untuk menemukan gambaran umum mengenai topok yang diteliti, eksplorasi sebagai upaya mengklasifikasikan data-data, serta pelaksanaan penelitian yang dilaksanakan melalui wawancara, observasi, studi dokumentasi dan studi litelatur.

\section{HASIL DAN PEMBAHASAN}

Berdasarkan studi pendahuluan yang dilakukan pada bulan Januari di RA AlMuqoddasah, Jagabaya, Banjaran, Kabupaten Bandung, ditemukan hal-hal berikut, yaitu dalam proses pembelajaran Al-Quran masih menggunakan cara konvensional. Anak-anak belajar menulis Al-Quran dengan mengikuti tulisan huruf hijaiyah yang ditulis guru di papan tulis. Guru membacakan huruf-huruf hijaiyah yang kemudian diikuti oleh anak-anak secara klasikal. Ada sebagian anak yang mengikuti dan ada juga yang asik dengan perhatiannya pada hal lain.

Dari hasil observasi tersebut, terlihat bahwa kegiatan pembelajaran Al-Quran masih menggunakan cara konvensional. Pengenalan literasi Al-Quran dilakukan dengan tidak menyenangkan untuk anak. Tandayu (Tandayu, 2001) mengatakan bahwa secara umum terkait dengan sifat fitrahnya, anak-anak menyukai kegiatan yang bernuansa B-C-M, yaitu bermain, becerita dan bernyanyi. Dalam hal ini, kegiatan literasi Al-Quran (baca-tulis) untuk anak usia dini akan lebih efektif dengan menggunakan tiga hal tersebut. Oleh karena itu, pengenalan literasi AlQuran dilakukan dengan teknik bercerita. Guru mengemas pembelajran membaca dan menulis Al-Quran melalui kegiatan bercerita.

Pada kegiatan literasi Al-Quran dengan teknik bercerita ini, cerita yang disampaikan adalah cerita yang berasal dari Al-Quran. Cerita-cerita tersebut dipilih berdasarkan topik-topik yang disukai oleh anak-anak, seperti cerita binatang. Beberapa cerita yang di sampaikan pada anak-anak yaitu : Raja Abrahah, Nabi Sulaeman dan Rombongan Semut, Ashabul Kahfi, Qorun yang kikir, Ratu Balqis dan burung Hud-hud, Nabi Ismail, Nabi Musa dan Nabi Khidzir, dan Nabi Nuh. Literasi Al-Quran melalui teknik bercerita lebih 
menekankan pada pengenalan kosakata yang berkaitan dengan cerita seperti pada kisah Raja Abrahah : fiilun, duudun dan waroqun.

Pada literasi Al-Quran melalui teknik bercerita ada lima hal yang menjadi penilaian yaitu : kemampuan anak menyebutkan tokoh dalam cerita, kemampuan anak menyebutkan kembali 2 kosakata bahasa Arab, kemampuan anak menceritakan kembali dengan bahasa yang sederhana, kemampuan anak menyebutkan 3-4 kosakata yang beritan dengan cerita dengan benar dan keberanian anak untuk bercerita di depan di depan kelas serta melafalkan kosakata-kosakata yang terdapat dalm cerita.

Kegiatan literasi Al-Quran pada anak-anak kelompok A melalui teknik bercerita. Kemampuan anak dalam menyebutkan tokoh dalam cerita : $51,5 \%$ anak mampu menyebutkan tokoh dengan baik, 6,2\% anak mampu menyebutkannya tokoh-tokohnya dengan benar, 32,8\% mampu menyebutkan tokoh dengan bantuan guru, dan 9,3\% masih malu-malu dan belum benar. Pada pelafalan atau pengucapan 2 kosakata yang berkaitan dengan cerita $54,6 \%$ anak sudah mampu mengucapkan kembali dengan baik, 6,2\% mengucapkan kembali dengan benar, dan $39 \%$ mampu mengucapkan walaupun terkadang di bimbing guru. Menceritakan kembali isi cerita 59,3\% sudah mampu walupun masih memerlukan memerlukan bimbingan, 29, 6\% sudah baik, 1,5\% mampu menceritakan kembali dengan baik dan benar, dan $9 \%$ masih perlu dorongan dan bimbingan. Untuk kemampuan mengucapkan 3-4 kosakata 45,3\% mampu walaupun masih ada beberapa kesalahan, $37,5 \%$ sudah baik, 6,2\% sudah baik dan benar, sedangkan 10,9\% masih memerlukan dorongan dan bimbingan. Kemampuan anak untuk menceritakan kembali serta mengucapkan kosakata bahasa Arab : 40,6\% sudah mulai berkembang atau anak sudah mulai mampu berani walaupun masih memerlukan ada beberapa kesalahan, 35,9\% sudah mampu dan baik, 10,9\% sudah mampu baik dan benar serta tanpa bantuan guru dan 12,5\% masih memerlukan dorongan untuk berani bercerita. Berikut ini grafik penjelasannya :

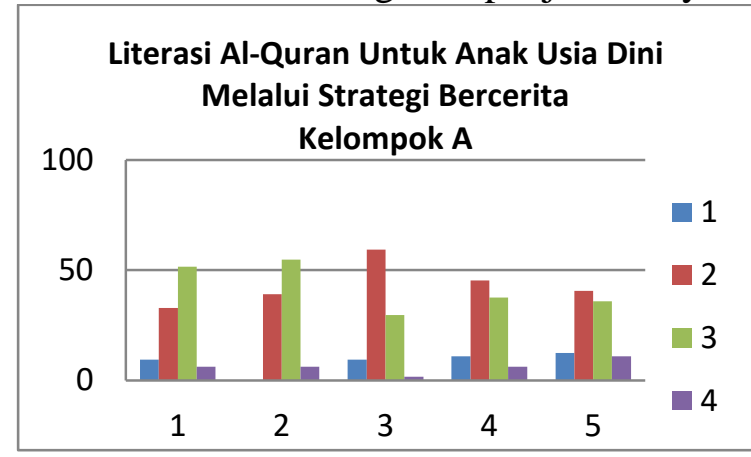

Strategi bercerita pada anak usia dini sangatlah penting. Melalui strategi bercerita anak dapat mencurahkan berbagai ide dan pengetahuan yang mereka miliki tanpa ada rasa takut untuk mengungkapkannya. Hal ini terbukti dari hasil wawancara dengan guru menyatakan bahwa $75 \%$ anak pada kelompok $\mathrm{A}$ menyenangi kegiatan literasi Al-Quran melalui teknik bercerita, sehingga anakanak dapat mengingat beberapa kosakata yang ada dalam cerita seperti fiilun, thoirun, jundiyun, dan dudun.

Kegiatan bercerita membuat anak merasa nyaman dan aman. Pesan-pesan moral dapat di sampaikan pada anak dengan mudah, jelas tanpa ada kesan menggurui. Sehingga pesan moral pun dapat lama melekat bahkan di ingat sepanjang hidupnya. Senada dengan pernyataan ini Apriza menyatakan karena melalui cerita dengan tema yang sangat menghibur sesuai dengan kebutuhan dan daya tangkap anak, dapat memberikan respon terhadap anak untuk mengamati, mendengarkan dan mengimajinasikan apa yang ia tangkap tanpa memperhatikan hal sekelilingnya. (Apriza, 2017). Sedangkan Suhendan menyatakan Storytelling is the most authentic and popular activity for all children. Kegiatan bercerita adalah kegiatan yang otentik dan populer pada anak usia dini(Sühendan, 2013)

Pembelajaran literasi Al-Quran untuk anak kelompok B. 37,5\% anak sudah dapat menyebutkan tokoh dalam cerita walaupun masih ada kesalahan, 32,2\% anak sudah mampu menyebutkan tokoh dengan baik, $15,6 \%$ anak sudah mampu menyebutkan tokoh dengan baik dan benar tanpa 
bimbingan dan 14,5\% masih memerlukan dorongan dan bimbingan. Mengucapkan 2 kosakata : 30,2 anak sudah mulai berkembang atau sudah mulai mampu mengucapkan, $\quad 31,2 \% \quad$ mampu mengucapkan dengan baik, 23,9 sudah mampu mengucapkan dengan baik dan benar, sedangkan 14,5\% masih malu-malu. $45,8 \%$ anak mulai mampu menceritakan kembali isi cerita, 30,2\% anak mampu meceritakan kembali dengan baik, 11,4\% kemampuan menceritakannya sangat baik, sedangkan 12,5 masih memerlukan bimbingan. Dalam melafalkan 3-4 kosakata $34,3 \%$ mulai mampu untuk mengucapkan, 35,4\% mampu melafalkan dengan baik, 15,6\% mampu melafalakan dengan baik dan benar, 14,5 masih perlu dorongan dan bimbingan. Kemampuan anak untuk menceritakan kembali disertai mengucapkan kosakata dalam cerita : 16,6 belum muncul kemampuannya, 40,6 mulai berkembang, 30,2\% berkembang dengan baik sesuai harapan dan $12,5 \%$ berkembang sangat baik. Berikut grafik perkembangannya :

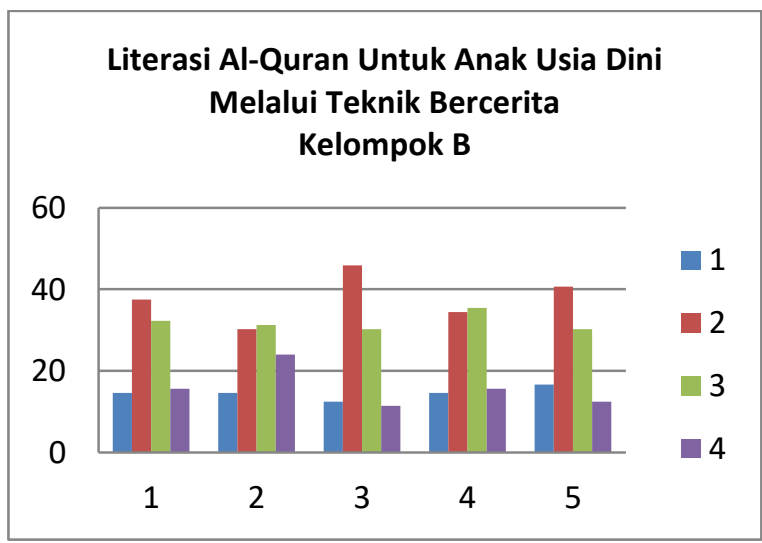

Pada literasi Al-Quran melalui teknik bercerita di kelompok B, hasil wawancara dengan guru menyatakan bahwa 41,6\% anak menyukai kegiatan literasi Al-Quran melalui teknik bercerita, terutama untuk kisah nabi Yunus dimana selain anak dapat mengingat dengan baik isi cerita mereka pun mampu melafalkan kosakata yang berkaitan dengan cerita seperti : qoribun, anbarun, bahrun dengan benar.

\section{SIMPULAN}

Hasil penelitian menunjukkan pada anak kelompok A 75\% anak menyenangi dan mampu mengikuti pembelajaran literasi Al-Quran dengan teknik bercerita sedangkan di kelompok B 41,6\% anak menyukai dan mampu mengikuti pembelajaran literasi Al-Quran dengan teknik bercerita. Hal ini menjelaskan bahwa teknik bercerita dalam pembelajaran literasi Al-Quran bagi anak usia dini di RA Al-Muqoddasah, Jagabaya, Banjaran, Kabupaten Bandung terbukti dapat menciptakan suasana menyenangkan bagi anak, sehingga anak tertarik dan dengan mudah dapat mengikuti pembelajaran literasi Al-Quran.

Bercerita sebagai salah satu bentuk kegiatan literasi berfungsi untuk menstimulasi potensi dan dan minat anak dalam kegiatan literasi Al-Quran. Oleh karena itu, literasi Al-Quran dengan teknik bercerita, selain anak mampu menceritakan kembali kisah-kisah yang ada dalam Al-Quran mereka pun mampu menyebutkan berbagai kosakata bahasa Arab baru bahkan mampu menuliskan kembali beberapa huruf dan kata dalam bahasa Arab yang berkaitan dengan kisah dalam Al-Quransehingga pembelajaran yang bermaknapun dapat terwujud.

\section{UCAPAN TERIMA KASIH}

Terima kasih penulis sampaikan kepada LPPM Universitas Islam Bandung, sebagai lembaga yang mempunyai andil besar dalam memberikan dukungan baik moril maupun materil dari awal pelaksanaan penelitian sampai dimuatnya artikel hasil penelitian di jurnal. Dan penulis haturkan terima kasih pula kepada tim redaksi serta revewer jurnal Obsesi yang telah menerima dan bersedia mengoreksi, memberikan saran serta masukkan agar artikel ini lebih baik dan sempurna sehingga dapat di terbitkan danartikel ini dapat memberikan tambahan ilmu bagi orang-orang yang berkecimbung di bidang pendidikan anak usia dini.

\section{DAFTAR PUSTAKA}

Aminudin, A. (2005). Pendidkan Kaum Perempuan. Jakarta: Jurnal Perempuan. 
210| Al-Quran Literacy for Early Childhood with Storytelling Techniques

Andalusia, N., \& Dkk. (2017). Literasi Dini denga Teknik Bercerita. Journal Family Edu, 3(1).

Anwar, R. (2014). Cara Mudah Memahami Bahasa AL-Quran. Bandung: Mizan.

Apriza, A. (2017). Pengaruh Biblioterapi Dengan Buku Cerita Bergambar Terhadap Tingkat Kecemasan Efek Hospitalisasi pada Anak Prasekolah. Jurnal Obsesi: Jurnal Pendidikan Anak Usia Dini, 1(2), 148-155.

Astuti, T. (2012). Gambaran Perkembangan Literasi Emergen Anak Taman Kank-Kanak dengan Alat Ukur Adaptasi Geat Ready To Read. Semarang: Universitas Diponogoro.

Bunanta, M. (2008). Mendongeng dan Minat Membaca. Jakarta: KPBA.

Departemen Pendidikan Nasional. (2009). Permendiknas 58 tahun 2009 tentang Standar Pendidikan Anak Usia Dini.

Fauziddin, M. (2017). Upaya Peningkatan Kemampuan Bahasa Anak Usia 4-5 Tahun melalui Kegiatan Menceritakan Kembali Isi Cerita Di Kelompok Bermain Aisyiyah Gobah Kecamatan Tambang. Jurnal Obsesi: Jurnal Pendidikan Anak Usia Dini, 1(1).

Musfiroh. (2005). Cerita untuk Anak Usia Dini. Yogyakarta: Tiarawacana.

Papalia, D. E., \& Olds, S. W. (2002). A Child's World, Infancy though Adolescence, Ninth Edition. Boston: McGraw-Hill.

Putri, P. (2017). Analisis Kemampuan Bahasa Dan Kemampuan Moral Pada Anak Usia Dini Melalui Metode Dongeng. Jurnal Obsesi: Jurnal Pendidikan Anak Usia Dini, 1(2).

Sholehudin, K. (1997). Dasar Pendidikan Anak Prasekolah. Bandung: IKIP.

Sühendan, E. (2013). Using Total Physical Response Method in Early Childhood Foreign Language Teaching Environments. Procedia -
Social and Behavioral Sciences, 93, 1766-1768.

https://doi.org/10.1016/j.sbspro.2013 .10 .113

Sulaeman, D. (2007). Doktor Cilik Hafal dan Faham Al-Quran. Jakarta: Imam.

Sulaiman, A. A. A. (2000). Metode Pendidikan Anak Muslim Usia Pra Sekolah. Jakarta: Darul Haq.

Tandayu, T. (2001). Memaknai Cerita Mengasah Jiwa (Panduan Menanamkan Nilai Moral pada Anak Melalui Cerita). Solo: Intermedia.

Thalib, M. (1995). 40 Tanggung Jawab Orang Tua Terhadap Anak. Bandung: Irsyad Baitus Salam.

Yusuf, S. (2004). Psikologi Belajar Agama. Pustaka Bani Quraisy: Pustaka Bani Quraisy. 